\section{THE VALUE OF ROUTINE X-RAYS IN DEMENTIA}

DeAR SiR,

We read with interest Dr Larkin's article (Journal, 146, January $1985,62-65$ ) on routine $X$-rays in psychiatric patients. We have made a similar audit of our X-ray procedures in patients with dementia.

Routine chest X-rays on 123 demented patients consecutively admitted to our hospital for assessment showed the following abnormalities: enlarged heart (15 cases), cardiac failure (12 cases), chronic obstructive airways disease ( 9 cases), chest infection ( 8 cases), old calcified lesion ( 2 cases), multiple rib fractures with an apical pneumothorax (1 case), fluid in both costophrenic angles ( 1 case) and hiatus hernia ( 1 case). Although the chest $\mathrm{X}$-ray was of no value in the differential diagnosis of dementia in our series, cases of cryptic chest infection and cardiac failure were occasionally identified. We suggest that a routine chest $X$-ray is indicated not least for the recognition of these coincidental illnesses, treatment of which sometimes leads to an improvement in behaviour and in subsequent management of patients with primary dementia.

A skull X-ray performed in 120 of these patients revealed the following abnormalities: carotid syphon calcification (12 cases), calcification in the falx cerebri ( 1 case), lytic area of unknown origin in the occipital bone (1 case), osteoporosis (1 case) and Paget's disease ( 2 cases). These results were not particularly helpful in the diagnosis and management of our patients, which may support Dr Larkin's conclusion that skull $\mathrm{X}$-rays should not form part of the routine assessment of psychiatric patients. However, if this guideline had been followed, a resectable meningioma would have been missed in a 62 year old woman with an eighteen month history of dementia and absent focal neurological signs. On rare occasions, bony changes on the skull $\mathrm{X}$-ray may be the first indication of a meningioma or of metastases.

E. B. Renvolze

R. K. GASKELL

H. M. KLAR

Bootham Park Hospital, York YO3 $7 B Y$

\section{KORO IN NON-CHINESE SUBJECTS}

\section{DeAR SiR,}

I wonder whether Koro is as exotic or rare a phenomenon as the literature suggests. Certainly over the years I have seen patients who have desribed shrinkage of the penis in a setting of depression.

Victor Gollancz the publisher in his autobio- graphical musings to his grandson "More for Timothy" gives a vivid description of a Koro-like syndrome- "I was afflicted during most of 1943 and part of 1944 ... There was not it is true, acute physical pain. But a dirty sort of pain, low, vague and indiscriminate, possessed the whole of my body, and made me abominable to my consciousness; and a more specialised phenomenon not only almost physically annihilated me whenever it appeared-and it appeared many times every day. . . For the instant I sat down . . . My member would disappear: I would feel it retiring into my body and would know myself . . . as not only unmanned, but dehumanised". He goes on to say, "I was utterly derelict and felt myself banished from life and from God. And I was quite hopeless".

This seems to be a description of a depressive illness with a delusional or over-valued idea in a man who had previously confessed in the first volume of his autobiography My Dear Timothy to masturbation guilt.

\section{Whittington Hospital, Psychiatric Wing, \\ Highgate Hill,} London N19 SNF

References

Gollancz, V. (1953) More for Timothy. London: Gollancz. (1952) My Dear Timothy. London: Gollancz.

\section{FALLING INCIDENCE OF SCHIZOPHRENIA?} DeAr Sir,

Eagles and Whalley (Journal, February 1985, 146, 151-154) offer the intriguing conclusion that their results "probably reflect a genuine fall in incidence" in schizophrenia over the decade studied. Extrapolation of their data would suggest that Scotland at least will be rid of new cases of schizophrenia by 1944 . Before policy makers begin planning for such an eventuality, it may be as well to take another look at more parsimonious explanations for these findings. The authors rightly acknowledge that, during the period they examined, two potent confounding factors were probably operating: the swing in diagnostic fashion away from schizophrenia and the increasing practice of community intervention and care. It may be that, as the authors claim, neither of these factors alone could sufficiently explain the decline in first admissions for schizophrenia in the observed absence of a concomitant change in the rates for paranoid states of mania. However, if one assumes, not unreasonably, that both these factors were at work simultaneously then they would surely conspire to produce precisely these data. Whilst each factor 